\title{
Tropical Seaweeds Improve Cardiovascular and Metabolic Health of Diet-Induced Obese and Hypertensive Rats ${ }^{\dagger}$
}

\author{
Ryan du Preez ${ }^{1}$, Sunil K. Panchal ${ }^{2}$ and Lindsay Brown ${ }^{3, *}$ \\ 1 School of Health, Medical and Applied Sciences, Central Queensland University, \\ Rockhampton, QLD 4701, Australia; r.dupreez@cqu.edu.au \\ 2 School of Science, Western Sydney University, Richmond, NSW 2753, Australia; \\ S.Panchal@westernsydney.edu.au \\ 3 School of Health and Wellbeing, University of Southern Queensland, Ipswich, QLD 4305, Australia \\ * Correspondence: Lindsay.Brown@usq.edu.au \\ + Presented at the 1st International Electronic Conference on Nutrients - Nutritional and Microbiota Effects \\ on Chronic Disease, 2-15 November 2020; Available online: https://iecn2020.sciforum.net/.
}

Published: 30 October 2020

\begin{abstract}
Seaweeds have been an important part of the diet of coastal populations in Asia possibly for millennia but only a few scattered coastal communities in Europe and the Americas have maintained these traditions. Our studies have investigated the potential of two tropical seaweeds grown commercially in Asia, Sarconema and Caulerpa spp., as functional foods for the reversal of metabolic syndrome and possible mechanisms. Sarconema spp. are a source of carrageenans used as thickening and gelling agents in foods while Caulerpa spp. are consumed in South-East Asia as lowenergy foods with high contents of vitamins and minerals. For our studies, male Wistar rats were divided into groups in a 16-week protocol: corn starch diet-fed rats (C); $\mathrm{C}$ rats supplemented with $5 \%$ dried seaweed for the last 8 weeks; high-carbohydrate, high-fat diet-fed rats $(\mathrm{H})$; and $\mathrm{H}$ rats supplemented with $5 \%$ dried seaweed for the last 8 weeks. H rats developed obesity, hypertension, dyslipidaemia, glucose intolerance, fatty liver and increased left ventricular collagen deposition, infiltration of inflammatory cells and plasma liver enzyme activities. Seaweed supplementation decreased body weight, abdominal and liver fat, systolic blood pressure, plasma lipid concentrations, plasma activities of liver enzymes and collagen deposition. Further, seaweed supplementation modulated gut microbiota. Possible mechanisms for improved cardiovascular and metabolic health include a reduced infiltration of inflammatory cells into organs as well as an increased intake of fibre modulating gut microbiota composition.
\end{abstract}

Keywords: metabolic syndrome; seaweeds; Sarconema; Caulerpa; gut microbiota; inflammation

\section{Introduction}

Seaweeds have generated extensive mythology, folklore and poetry around the world [1]. In ancient Japan and China, seaweeds were valued, even revered, and used to pay taxes or presented as a delicacy to honoured guests. However, they were not appreciated by the ancient Romans or Greeks and their consumption was a sign of penury or frugality in much of the Western world [1]. Globally, seaweeds are still under-utilised but the interest in seaweeds as foods or phycogastronomy is increasing [2].

Tropical fruits such as mangosteens, coffee and seaweeds have been evaluated as functional foods, defined as foods that provide nutrition as well as therapeutic benefits [3]. Seaweeds are an important part of traditional diets in many Asian countries such as Japan, Korea, China, Vietnam and the Philippines. Seaweeds are also an important product of aquaculture; the Food and Agriculture 
Organization of the United Nations reported in 2020 that total production of aquatic plants, mainly seaweeds and mainly by aquaculture, reached 32.4 million tonnes world-wide in 2018, with the three major species being the brown seaweed, Japanese kelp (Laminaria japonica; 11.5 million tonnes), the red seaweed, Eucheuma spp. (9.2 million tonnes) and the red seaweed, Gracilaria spp. (3.5 million tonnes) [4]. The related Kappaphycus and Eucheuma are the major red seaweeds commercially grown in the tropical waters of South-East Asia, especially Indonesia, the Philippines and Malaysia. This large-scale production has raised many issues including lack of seaweed biodiversity, lack of commercialisation of indigenous cultivars, failure to implement new farming techniques and environmental issues such as invasive organisms and plastics [5].

The use of seaweeds as raw materials for agriculture and industry is widespread. Waste algae have been successfully composted although there are many challenges to produce an effective product [6]. Biochar produced from seaweed biomass is high yield with nutrients including $\mathrm{N}, \mathrm{P}, \mathrm{K}$, $\mathrm{Ca}, \mathrm{Mg}$ and Mo, leading to reduced soil emissions of greenhouse gases, reduced nutrient leaching, reduced soil acidity, and reduced irrigation and fertiliser requirements [7] as well as 35-40\% increased growth of radishes [8]. Seaweeds are effective in removing pollutants such as dyes, nitrogen, phosphorus and heavy metals from wastewater [9]. Freshwater macroalgae were used to recover $\mathrm{N}$ and P from municipal wastewater to then increase agricultural productivity in low fertility soil [10]; this action also decreases the access of these pollutants from coastal cities to the surrounding ocean. Freshwater macroalgae can effectively bioremediate effluents from coal-fired power stations [11]. Further, the use of seaweed biomass to produce biofuels is now being intensively researched to decrease concerns about the depletion of fossil fuels [12]. Macroalgal polysaccharides such as alginates and carrageenans are potential sources of bio-based plastics as an alternative to fossil fuel [13]. In the oceans, physiological buffering by a marine alga since photosynthetic activity increases $\mathrm{pH}$ in the microenvironment which may ameliorate the negative effects of changing ocean conditions such as increased temperatures and carbon dioxide concentrations [14].

Seaweeds also have important roles in the food industry and health. Seaweeds added to foods such as meat, fish and bakery can improve shelf-life and overall quality of these foods [15]. There are extensive reviews on the potential usefulness of seaweeds in health $[16,17]$, especially concerning the roles of polysaccharides as prebiotics [18]. One particular emphasis is the role of seaweeds to attenuate the signs of metabolic syndrome, especially obesity and hypertension [19-21]. While seaweeds can provide a sustainable source of nutrients as well as many health interventions, there are potential risks in seaweed consumption, such as excess intake of iodine and heavy metals such as arsenic [22].

This project has investigated the effectiveness of two tropical seaweeds, Sarconema filiforme and Caulerpa lentillifera, to attenuate the signs of metabolic syndrome in rats following a diet high in simple sugars such as fructose and sucrose as well as saturated fats. We have determined the changes in cardiovascular, liver and metabolic parameters.

\section{Methods}

Source of seaweeds: S. filiforme was cultured at the University of the Sunshine Coast seaweed aquaculture facility at the Bribie Island Research Centre, Woorim, QLD, Australia $\left(27^{\circ} 04^{\prime} 10^{\prime \prime}\right.$ S; $153^{\circ} 12^{\prime} 15^{\prime \prime}$ E) from January to March 2018. C. lentillifera was purchased from Viet Delta Corporation (http://vdelta.com.vn/c/3/seaweed?pagenumber=2\#), Ho Chi Minh City, Vietnam.

Rats and diets: Male Wistar rats (8-9 weeks old; 330-340 g) were obtained from the Animal Resource Centre, Murdoch, WA, Australia. Rats were randomly allocated to four groups for each intervention, each of 12 rats. Two groups were fed either corn starch or high-carbohydrate, high-fat diets ( $\mathrm{C}$ and $\mathrm{H}$, respectively) [23] for the full 16 weeks. The other two groups received $\mathrm{C}$ and $\mathrm{H}$ diets for eight weeks and then received either $5 \%$ S. filiforme or $C$. lentillifera mixed in the food for the final eight weeks. Rat measurements of body weights, food and water intakes, abdominal circumference, systolic blood pressure, body composition by dual energy X-ray absorptiometry, oral glucose and insulin tolerance, indirect calorimetry, plasma measurements, isolated Langendorff heart preparation, 
organ weights, plasma measurements, histological analyses and gut microbiota, together with statistical analyses, have been previously described [23,24].

\section{Results and Discussion}

Rats fed for 16 weeks with a diet high in simple sugars and saturated fats developed the signs of metabolic syndrome, including obesity, hypertension, dyslipidaemia, glucose intolerance, fatty liver and increased left ventricular collagen deposition. We then used a reversal protocol to determine whether intervention with either S. filiforme or C. lentillifera attenuated these physiological changes. Both interventions decreased body weight, systolic blood pressure, left ventricular stiffness, visceral adiposity, plasma cholesterol concentrations and infiltration of inflammatory cells into the heart and liver $[24,25]$. These results are consistent with our previous study on the red seaweed, Kappaphycus alvarezii [26]. These changes show that both seaweeds can be described as functional foods to improve diet-induced metabolic syndrome. Since obesity is described as a low-grade chronic inflammation, the anti-inflammatory responses to both seaweed interventions are likely to be the mechanism for the observed changes.

Further, for both seaweeds, the alterations in the bacterial community structure correlated with the physiological data [24,25], suggesting that the changes in the gut microbiota produced the changes in the physiological parameters in the rats with diet-induced metabolic syndrome. Since both seaweeds are important sources of dietary fibre, this indicates that the seaweed polysaccharides are acting as prebiotics to change bacterial composition in the colon. Prebiotics have been proposed as effective treatments for obesity and NAFLD with plausible mechanisms of action $[27,28]$. Thus, our results support the concept that these seaweeds improve cardiovascular, liver and metabolic health by prebiotic actions in the colon.

\section{Conclusions}

Rats fed a diet with increased simple carbohydrates and saturated fatty acids developed the cardiovascular, liver and metabolic signs of metabolic syndrome. Addition of either S. filiforme or C. lentillifera to the diet reversed these diet-induced changes. Likely mechanisms of actions include markedly decreased infiltration of inflammatory cells into the organs of the body together with prebiotic actions in the gastrointestinal tract. These studies then define both seaweeds as functional foods. Large-scale cultivation of these seaweeds in tropical waters can support the production of high-value health products as additional uses for the seaweeds including as animal food, as broadspectrum crop fertilisers, to remediate agricultural and industrial waste-water and to store energy as biofuels [29].

Acknowledgments: The authors thank the University of Southern Queensland for postgraduate research scholarship for R.d.P. and Strategic Research Initiative support, Nicholas Paul at the University of the Sunshine Coast for S. filiforme, Peter Mouatt at Southern Cross University for chemical analyses, and Marwan Majzoub and Torsten Thomas at the University of New South Wales for gut microbiota analyses.

\section{References}

1. Pérez-Lloréns, J.L.; Mouritsen, O.G.; Rhatigan, P.; Cornish, M.L.; Critchley, A.T. Seaweeds in mythology, folklore, poetry, and life. J. Appl. Phycol. 2020, 32, 3157-3182, doi:10.1007/s10811-020-02133-0.

2. Mouritsen, O.G.; Rhatigan, P.; Pérez-Lloréns, J.L. The rise of seaweed gastronomy: Phycogastronomy. Bot. Mar. 2019, 62, 195-209, doi:10.1515/bot-2018-0041.

3. John, O.D.; Du Preez, R.; Panchal, S.K.; Brown, L. Tropical foods as functional foods for metabolic syndrome. Food Funct. 2020, 11, 6946-6960, doi:10.1039/d0fo01133a.

4. Food and Agriculture Organization. The State of World Fisheries and Aquaculture-Sustainability in Action. Available online: http://www.fao.org/3/ca9229en/CA9229EN.pdf (accessed on 14 October 2020).

5. Hurtado, A.Q.; Neish, I.C.; Critchley, A.T. Phyconomy: The extensive cultivation of seaweeds, their sustainability and economic value, with particular reference to important lessons to be learned and 
transferred from the practice of eucheumatoid farming. Phycologia 2019, 58, 472-483, doi:10.1080/00318884.2019.1625632.

6. Han, W.; Clarke, W.; Pratt, S. Composting of waste algae: A review. Waste Manag. 2014, 34, 1148-1155, doi:10.1016/j.wasman.2014.01.019.

7. Bird, M.I.; Wurster, C.M.; de Paula Silva, P.H.; Paul, N.A.; De Nys, R. Algal biochar: Effects and applications. GCB Bioenergy 2012, 4, 61-69, doi:10.1111/j.1757-1707.2011.01109.x.

8. Roberts, D.A.; Paul, N.A.; Cole, A.J.; de Nys, R. From waste water treatment to land management: Conversion of aquatic biomass to biochar for soil amelioration and the fortification of crops with essential trace elements. J. Environ. Manag. 2015, 157, 60-68, doi:10.1016/j.jenvman.2015.04.016.

9. Arumugam, N.; Chelliapan, S.; Kamyab, H.; Thirugnana, S.; Othman, N.; Nasri, N.S. Treatment of wastewater using seaweed: A review. Int. J. Environ. Res. Public Health 2018, 15, doi:10.3390/ijerph15122851.

10. Cole, A.J.; Paul, N.A.; de Nys, R.; Roberts, D.A. Good for sewage treatment and good for agriculture: Algal based compost and biochar. J. Environ. Manag. 2017, 200, 105-113, doi:10.1016/j.jenvman.2017.05.082.

11. Roberts, D.A.; Paul, N.A.; Bird, M.I.; de Nys, R. Bioremediation for coal-fired power stations using macroalgae. J. Environ. Manag. 2015, 153, 25-32, doi:10.1016/j.jenvman.2015.01.036.

12. Del Rio, P.G.; Gomes-Dias, J.S.; Rocha, C.M.R.; Romani, A.; Garrote, G.; Domingues, L. Recent trends on seaweed fractionation for liquid biofuels production. Bioresour. Technol. 2020, 299, 122613, doi:10.1016/j.biortech.2019.122613.

13. Zhang, C.; Show, P.L.; Ho, S.H. Progress and perspective on algal plastics - A critical review. Bioresour. Technol. 2019, 289, 121700, doi:10.1016/j.biortech.2019.121700.

14. Doo, S.S.; Leplastrier, A.; Graba-Landry, A.; Harianto, J.; Coleman, R.A.; Byrne, M. Amelioration of ocean acidification and warming effects through physiological buffering of a macroalgae. Ecol. Evol. 2020, 10, 8465-8475, doi:10.1002/ece3.6552.

15. Roohinejad, S.; Koubaa, M.; Barba, F.J.; Saljoughian, S.; Amid, M.; Greiner, R. Application of seaweeds to develop new food products with enhanced shelf-life, quality and health-related beneficial properties. Food Res. Int. 2017, 99, 1066-1083, doi:10.1016/j.foodres.2016.08.016.

16. Salehi, B.; Sharifi-Rad, J.; Seca, A.M.L.; Pinto, D.; Michalak, I.; Trincone, A.; Mishra, A.P.; Nigam, M.; Zam, W.; Martins, N. Current trends on seaweeds: Looking at chemical composition, phytopharmacology, and cosmetic applications. Molecules 2019, 24, 4182, doi:10.3390/molecules24224182.

17. de Jesus Raposo, M.F.; de Morais, A.M.B.; de Morais, R.M.S.C. Marine polysaccharides from algae with potential biomedical applications. Mar. Drugs 2015, 13, 2967-3028, doi:10.3390/md13052967.

18. Cherry, P.; Yadav, S.; Strain, C.R.; Allsopp, P.J.; McSorley, E.M.; Ross, R.P.; Stanton, C. Prebiotics from seaweeds: An ocean of opportunity? Mar. Drugs 2019, 17, 327, doi:10.3390/md17060327.

19. Chu, W.-L.; Phang, S.-M. Marine algae as a potential source for anti-obesity agents. Mar. Drugs 2016, 14, 222, doi:10.3390/md14120222.

20. Seca, A.M.L.; Pinto, D. Overview on the antihypertensive and anti-obesity effects of secondary metabolites from seaweeds. Mar. Drugs 2018, 16, 237, doi:10.3390/md16070237.

21. Gabbia, D.; De Martin, S. Brown seaweeds for the management of metabolic syndrome and associated diseases. Molecules 2020, 25, 4182, doi:10.3390/molecules25184182.

22. Cherry, P.; O’Hara, C.; Magee, P.J.; McSorley, E.M.; Allsopp, P.J. Risks and benefits of consuming edible seaweeds. Nutr. Rev. 2019, 77, 307-329, doi:10.1093/nutrit/nuy066.

23. Panchal, S.K.; Poudyal, H.; Iyer, A.; Nazer, R.; Alam, M.A.; Diwan, V.; Kauter, K.; Sernia, C.; Campbell, F.; Ward, L., et al. High-carbohydrate, high-fat diet-induced metabolic syndrome and cardiovascular remodeling in rats. J. Cardiovasc. Pharmacol. 2011, 57, 611-624, doi:10.1097/FJC.0b013e31821b1379.

24. du Preez, R.; Paul, N.; Mouatt, P.; Majzoub, M.E.; Thomas, T.; Panchal, S.K.; Brown, L. Carrageenans from the red seaweed Sarconema filiforme attenuate symptoms of diet-induced metabolic syndrome in rats. Mar. Drugs 2020, 18, 97, doi:10.3390/md18020097.

25. du Preez, R.; Majzoub, M.E.; Thomas, T.; Panchal, S.K.; Brown, L. Caulerpa lentillifera (sea grapes) improves cardiovascular and metabolic health of rats with diet-induced metabolic syndrome. 2020, under review for publication.

26. Wanyonyi, S.; du Preez, R.; Brown, L.; Paul, N.A.; Panchal, S.K. Kappaphycus alvarezii as a food supplement prevents diet-induced metabolic syndrome in rats. Nutrients 2017, 9, 1261, doi:10.3390/nu9111261.

27. Cerdó, T.; García-Santos, J.A.; G Bermúdez, M.; Campoy, C. The role of probiotics and prebiotics in the prevention and treatment of obesity. Nutrients 2019, 11, 635, doi:10.3390/nu11030635. 
28. Duarte, S.M.B.; Stefano, J.T.; Oliveira, C.P. Microbiota and nonalcoholic fatty liver disease/nonalcoholic steatohepatitis (NAFLD/NASH). Ann. Hepatol. 2019, 18, 416-421, doi:10.1016/j.aohep.2019.04.006.

29. Bikker, P.; van Krimpen, M.M.; van Wikselaar, P.; Houweling-Tan, B.; Scaccia, N.; van Hal, J.W.; Huijgen, W.J.; Cone, J.W.; Lopez-Contreras, A.M. Biorefinery of the green seaweed Ulva lactuca to produce animal feed, chemicals and biofuels. J. Appl. Phycol. 2016, 28, 3511-3525, doi:10.1007/s10811-016-0842-3.

Publisher's Note: MDPI stays neutral with regard to jurisdictional claims in published maps and institutional affiliations.

(C) 2020 by the authors. Licensee MDPI, Basel, Switzerland. This article is an open access article distributed under the terms and conditions of the Creative Commons Attribution (CC BY) license (http://creativecommons.org/licenses/by/4.0/). 